\title{
GROWTH, ANATOMY AND PHYSIOLOGY OF COFFEE PLANTS INTOXICATED BY THE HERBICIDE GLYPHOSATE
}

\author{
Dalyse Toledo Castanheira ${ }^{1}$, Ademilson de Oliveira Alecrim², Giovani Belutti Voltolini ${ }^{3}$, \\ Tiago Teruel Rezende ${ }^{4}$, Pedro Menicucci Netto ${ }^{5}$, Rubens José Guimarães ${ }^{6}$
}

(Received: October 08, 2018; accepted: January 21, 2019)

\begin{abstract}
Weed control is fundamental in coffee cultivation due to their high interference, competing with the crop for water, light and nutrients. Among the control methods used, chemical control is highlighted, due to its high efficiency and low cost. However, due to application failures, herbicide drift phytotoxicity is common. Aiming at the search for selective active ingredients in coffee, the objective of this study was to growth, anatomy and physiology of coffee plants intoxicated by the herbicide Glyphosate. The experiment was carried out in a greenhouse with 'Topázio MG1190' coffee plants (Coffea arabica L.), cultivated in pots with an 11 L-substrate capacity. The statistical design was randomized block design (RBD), with four replicates and four doses of the herbicide, making up 16 experimental plots. Each plot consisted of three plants. The treatments were: (i) $0 \%$; (ii) $10 \%$; (iii) $25 \%$ and (iv) $50 \%$ of the commercial dose of the herbicide Glyphosate. The evaluations were performed at 104 days after application of the treatments. Growth, morphological, and physiological characteristics were evaluated. The effect of glyphosate drift impairs plant growth. However, after 104 days of intoxication, there is no longer any effect on the physiology and leaf anatomy of coffee plants.
\end{abstract}

Index Terms: Selectivity; chemical control; Coffea arabica L.

\section{CRESCIMENTO, ANATOMIA E FISIOLOGIA DE CAFEEIROS INTOXICADOS PELO HERBICIDA GLYPHOSATE}

\begin{abstract}
RESUMO: O controle de plantas daninhas é fundamental na cafeicultura devido à elevada interferência que as mesmas implicam, competindo com a cultura por água, luz e nutrientes. Dentre os métodos de controle utilizados destaca-se o controle químico, por sua alta eficiência e baixo custo. Contudo, devido a falhas na aplicação, são frequentes casos de fitotoxicidade pela deriva dos herbicidas. Visando a busca por ingredientes ativos seletivos ao cafeeiro, objetivou-se com este trabalho, avaliar o crescimento, anatomia e fisiologia de plantas de cafeeiro intoxicadas pelo herbicida Glyphosate. O experimento foi realizado em casa de vegetação, com plantas de cafeeiro (Coffea arabica L.) da cultivar Topázio MG1190, cultivadas em vasos com capacidade de 11 litros de substrato. O delineamento estatístico utilizado foi o Delineamento em Blocos Casualizados (DBC), com quatro repetições e quatro doses do herbicida, perfazendo, 16 parcelas experimentais. Cada parcela foi composta por três plantas. Os tratamentos foram: (i) $0 \%$; (ii) $10 \%$; (iii) $25 \%$ e (iv) $50 \%$ da dose comercial do herbicida Glyphosate. As avaliações foram realizadas aos 104 dias após a aplicação dos tratamentos. Foram avaliadas características de crescimento, fisiológicas e anatômicas. O efeito da deriva de glyphosate prejudica o crescimento das plantas, porém após 104 dias da ocorrência da intoxicação já não se observa consequências na fisiologia e na anatomia foliar dos cafeeiros.
\end{abstract}

Termos indexados: Fitotoxicidade, seletividade, controle químico, café.

\section{INTRODUCTION}

The coffee agribusiness is of great importance in the Brazilian economy, and it is responsible for the generation of income and jobs (CAIXETA, 2008). According to CONAB (2018), the Brazilian production expected for 2018 is between 54.4 and 58.5 million $60 \mathrm{~kg}$-processed bags, which is higher than the previous year. However, coffee crop yield is directly related to several factors, among them, soil fertility, plant nutrition, phytosanitary control, application technologies, climatic conditions and weed management can be highlighted (OLIVEIRA, 2013).
In this context, weed incidence stands out as one of the most important, mainly due to the competition with coffee for water, light and nutrients (FIALHO et al, 2011; LORENZI, 2014). In addition, it may also hamper crop cultivation, such as fertilization, harvesting and pest and disease control (RONCHI et al., 2003b).

The period of greatest crop sensitivity to weed incidence occurs in the first year of implantation, mainly in the planting line, where it is frequently necessary to adopt manual control, which is more difficult and costly due to the increasing scarcity of manpower in the field and

1,2,3,5,6 Universidade Federal de Lavras/UFLA - Departamento de Agricultura/DAG - Cx. P. 3037 - 37.200-000 Lavras-MG-dalysecastanheira@hotmail.com,ademilsonagronomia@gmail.com,giovanibelutti77@hotmail.com, pedromenicucci2010@hotmail.com, rubensjg@dag.ufla.br

${ }^{4}$ Universidade José do Rosário Vellano - Rodovia MG 179, km 0 - Campus Universitário - 37.152- 440 - Alfenas - MG tiago.rezende@unifenas.br 
the high rainfall that coincides with the time of greatest weed interference in the crop. In this context, a viable alternative for an efficient weed control in the coffee crop is by herbicides (RONCHI et al., 2001).

However, even though there are several herbicides registered for weed control in coffee cultivation, few are those that show total selectivity for direct application on coffee (ALCÂNTARA, 2000). It is emphasized that these non-selective herbicides should be used with caution, avoiding them to reach the crop, causing phytotoxicity symptoms (SILVA et al., 2017).

Glyphosate is one of the main non-selective herbicides used in coffee plants. However, due to the occurrence of winds and the lack of use of recommended application technologies, product drift can occur, reaching the crop and, consequently, causing phytotoxicity symptoms (RONCHI et al., 2003a).

Several studies have demonstrated the characterization of these symptoms by the appearance of chlorotic, small and brittle leaves, similar to those of nutritional deficiencies of nitrogen (N), boron (B) and zinc (Zn) (FRANÇA, et al., 2010b). However, there is a lack of studies that associate the appearance of these visual characteristics with the internal modifications in plants, as well as with the physiological changes caused by these alterations. The objective of this study was to evaluate the changes in the anatomical and physiological characteristics of coffee plants intoxicated by the herbicide Glyphosate.

\section{MATERIAL AND METHODS}

The trial was carried out in a greenhouse in the municipality of Lavras-MG, located in the southern region of the state of Minas Gerais, at an altitude of $918 \mathrm{~m}, 21^{\circ} 14^{\prime} \mathrm{S}$ latitude and $45^{\circ} 00^{\prime} \mathrm{W}$ longitude, from December 2016 to March 2017. The annual average air temperature is $19.4{ }^{\circ} \mathrm{C}$, with a maximum of $26.1{ }^{\circ} \mathrm{C}$ and the minimum, $14.4{ }^{\circ} \mathrm{C}$.

For the simulation of intoxication, 'Topázio MG1190' coffee (Coffea arabica L.) seedlings were planted in 11-L pots, with 4-5 pairs of leaves. A randomized block design with four replicates and four doses of the herbicide Glyphosate was used: (i) $0 \%$; (ii) $10 \%$; (iii) $25 \%$ and (iv) $50 \%$ of the recommended commercial dose $(3.0 \mathrm{~L}$ $\mathrm{ha}^{-1}$ ) applied directly to coffee plants. Each plot consisted of three plants.
The application of the herbicide at different doses was carried out using a $\mathrm{CO}_{2}$ pressurized costal sprayer, with pressure of 45 pounds, and the spray bar directed close to the top of the plants, with a spray volume of 300 L.ha $^{-1}$. After the application, the plants remained in the greenhouse for 104 days, daily irrigated, aiming at the maintenance of field capacity $(100 \%)$. The management and cultural treatment were carried out as recommended by Matiello (2010).

Visual observation and imaging of the symptoms caused by the action of the herbicide were performed daily. The anatomical and physiological evaluations of the plants were performed at the end of the experiment. The following growth characteristics were evaluated: plant height, measured in centimeters from the ground level to the apical bud of the orthotropic branch; number of leaves; stem diameter, measured in millimeters at the collar of the plants; number of plagiotropic branches; leaf area, in $\mathrm{cm}^{2}$, quantified by leaf discs (Cunha et al., 2010); shoot, root, plagiotropic branches, ortotropic branche and leaf dry matter, in grams. Root length analysis, in centimeters, was also determined by the sum of the linear extension of each fragment of the root system and the mean root diameter, in centimeters, both using the imaging software Safira (JORGE; SILVA, 2010).

For the evaluation of leaf anatomy, at 104 days, leaves located between the second and third node of the plagiotropic branch of the plants were collected. Subsequently, in the laboratory, the paradermic and transverse sections were performed. Those paradermic were obtained before of collection, using the universal instant adhesive (cyanoacrylate ester) method (SEGATTO et al., 2004). In order to obtain the cross sections, the plant material underwent dehydration in an ethylic series, and then immersed in methacrylate (methodology according to the manufacturer) and sectioned with $0.8 \mu \mathrm{m}$ thickness using a rotary microtome. Subsequently, these were stained with toluidine blue (O’brien; Feder; Mccully, 1964) and the blades were assembled using Entelan ${ }^{\circledR}$ as a medium. The slides of both sections (paradermic and transverse) were observed and photographed under an optical microscope coupled to a digital camera. The images obtained were analyzed in the UTHSCSA-Imagetool program and then the stomatal characteristics, leaf tissues and vascular bundles were evaluated. For the stomatal characterization, the following characteristics 
were evaluated: stomatal number; polar diameter of the stomata and equatorial diameter of the stomata. Stomatal density (number of stomata per $\mathrm{mm}^{2}$ ) and the polar diameter/equatorial diameters stomatal ratio, which is highly correlated with stomatal functionality (Silva, et al., 2014, Souza et al., 2013), was calculated using these data. To evaluate leaf tissues, the following were measured: epidermal thickness of the adaxial face; thickness of the palisade parenchyma; thickness of the spongy parenchyma; and thickness of the mesophyll. In the evaluation of vascular bundles, the following parameters were measured: thickness of the phloem region; diameter of xylem vessels; and number of xylem vessels.

For the physiological analyses, a portable infrared gas analysis system (LICOR - 6400XT) was used to evaluate the net photosynthetic rate (A - $\mu \mathrm{mol} \mathrm{CO} 2 \mathrm{~m}^{-2} \mathrm{~s}^{-1}$ ), stomatal conductance (gs $\left.\mathrm{mol} \mathrm{H} 2 \mathrm{O} \mathrm{m}^{-2} \mathrm{~s}^{-1}\right)$, and transpiration rate $(\mathrm{E}-\mathrm{mmol}$ $\left.\mathrm{m}^{-2} \mathrm{~s}^{-1}\right)$. The water use efficiency (EiUA - $\mu \mathrm{mol}$ $\mathrm{CO}_{2} \mathrm{mmol}^{-1} \mathrm{H} 2 \mathrm{O}$ ), calculated by the $\mathrm{A} / \mathrm{E}$ ratio (Yan et al., 2015), was also evaluated. The evaluations were performed between 9 and 11 o'clock in the morning under artificial light $\left(1000 \mu \mathrm{mol} \mathrm{m}^{-2} \mathrm{~s}^{-1}\right)$, using leaves located between the second and third node of the plagiotropic branch of the plants.

For data analysis, the SISVAR Statistical Software (Ferreira, 2011) was used. For the response variables that showed differences ( $p$ $<0.05$ ), the regression models that were able to explain the variation maximum of the response variable as a function of herbicide doses were adjusted.

\section{RESULTS AND DISCUSSION}

By the observation of the symptoms and verification of the obtained images, the appearance of the phytotoxicity symptoms occurred from the $10^{\text {th }}$ day after the application of the herbicide Glyphosate. Initially, in the $10^{\text {th }}$ day leaves with mild chlorosis were observed in the meristematic regions; subsequently, after 20 days, leaf limb tightening and excessive shooting were observed in axillary bud regions. (Figures 1, 2 and 3).

Leaf chlorosis is related to the reduction in chlorophyll synthesis by the plant, since Glyphosate directly blocks its formation (TAN et al., 2006). However, leaf limb tightening maybe associated with dysfunction in the cell caused by the herbicide, causing that three essential amino acids are not produced for plant development, tyrosine, phenylalanine and tryptophan, from the inhibition of the site of action of the target enzyme, 5-enolpyruvyl-chiquimate-3-phosphate synthase (EPSPs) (ZABLOTOWICZ; REDDY, 2004).

The analysis of variance showed that the variables stem diameter, leaf number, number of plagiotropic branches, shoot and ortotropic dry matter, all physiological, anatomical and root system characteristics of the plants did not present significant differences $(\mathrm{p}<0.05)$ among the doses. However, for the variables height, leaf dry matter, leaf area and dry matter of plagiotropic branches, there was a significant difference.

Despite the initial symptoms after the application of the herbicide, the plants apparently presented recovery, without damage to the physiology and foliar anatomy, after 104 days of application. Tuffi Santos et al. (2008) did not observe variations in epidermal thickness in plants exposed to different doses of Glyphosate in the eucalyptus crop. However, Tuffi Santos et al. (2009) observed an increased thickness of the palisade parenchyma at 7 days after application of Glyphosate in doses from $345.6 \mathrm{~g} \mathrm{ha}^{-1}$ in three different eucalyptus clones. This variability in the occurrence of symptoms may have occurred due to the different clones used in the studies.

On the other hand, Reis (2013) observed that, with the increase in Glyphosate doses, there was a decrease in total leaf thickness in 'Catuaí' plants, due to the reduction in the palisade parenchyma, 30 days after application of herbicide.

There was no significant effect on the plants at 104 days after the simulated drift for the physiological characteristics. This may have occurred due to the fact that coffee plants have the ability to recover from the injuries inherent to the herbicide Glyphosate after a certain time after application. In this context, França et al. (2010a) observed a recovery of coffee plants at 120 days after application of Glyphosate, with a decrease in the intoxication level of the plants that received the herbicide. Likewise, Tuffi Santos et al. (2008) chose eucalyptus plants with symptoms of Glyphosate intoxication ranging from 0 to $50 \%$ of the dose in the field and verified that, after 180 days of application, the plants were recovered.

No significant differences were observed in the coffee seedlings for the characteristics related to the root system, and these results differ from those found by França et al. (2013), in which the authors found differences in root dry matter for cultivars Acaiá and Catuaí, using with up to $32 \%$ of the recommended herbicide dose. 


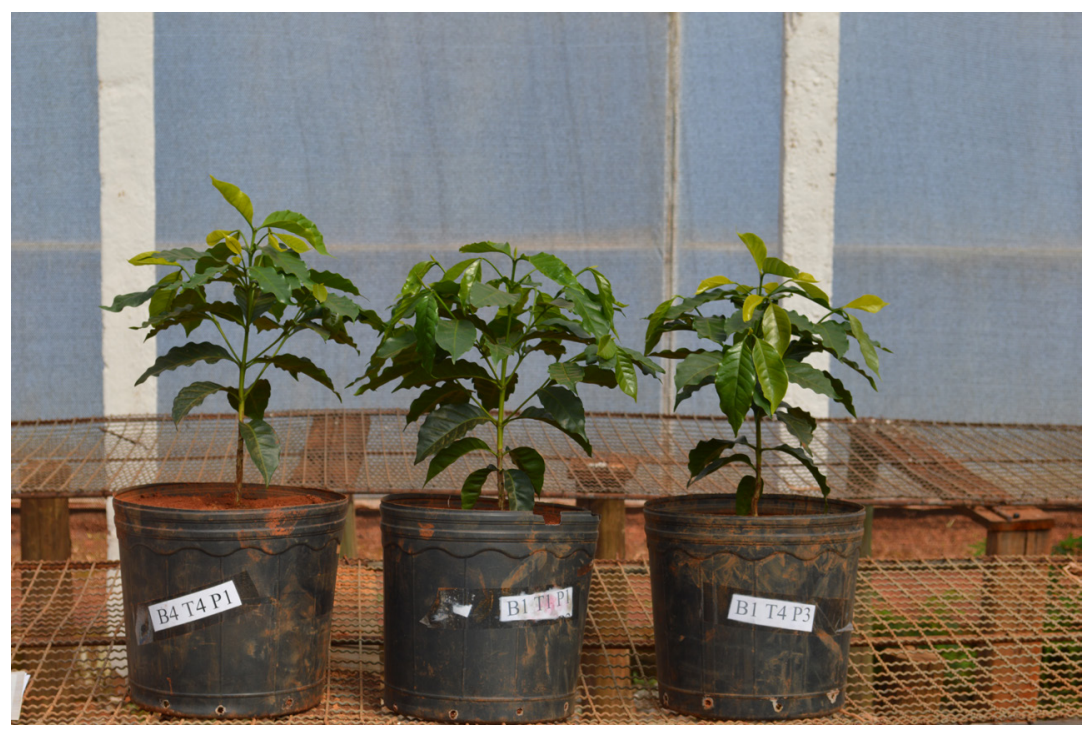

FIGURE 1 - Foliar chlorosis in the coffee growing regions submitted to the herbicide Glyphosate.

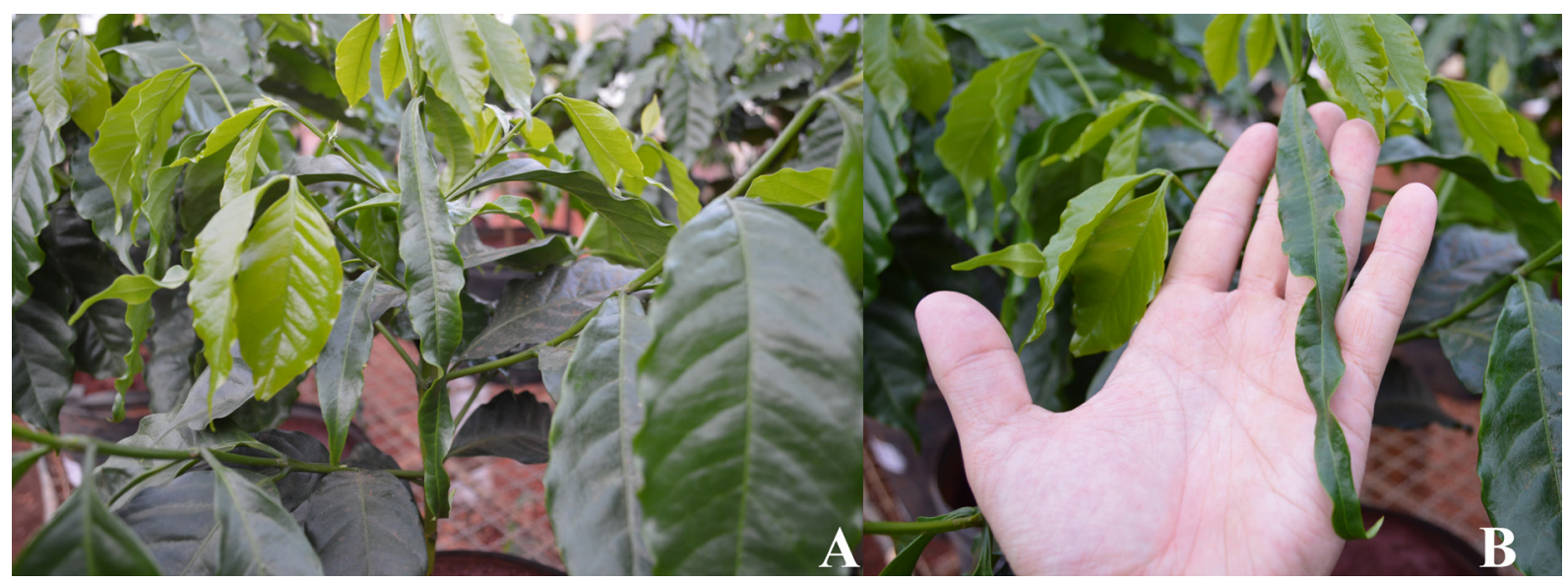

FIGURE 2 - (A) and (B) Leaf limb tightening in coffee plants submitted to the herbicide Glyphosate.

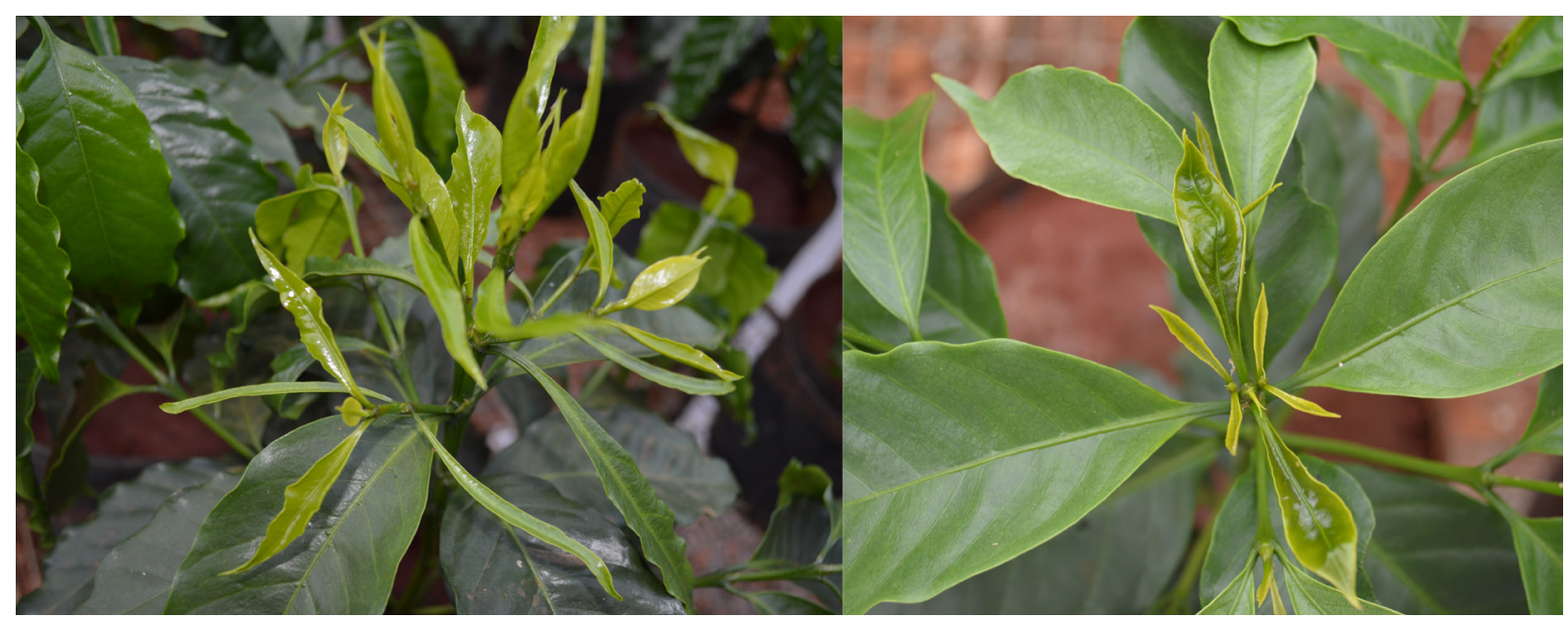

FIGURE 3 - Leaf limb tightening and excessive shooting in axillary bud regions in coffee plants submitted to the herbicide Glyphosate. 
However, Wagner Jr. et al. (2008) also reported that doses of Glyphosate applied on yellow passion fruit seedlings did not lead to reductions in root length at $28 \mathrm{DAA}$, up to $24 \%$ of the recommended herbicide dose, corroborating the results of this study.

In relation to the characteristics that presented significant differences, as the doses of the herbicide Glyphosate were increased, there was a linear decrease in values, in height, leaf area, leaf dry matter and in the dry matter of the plagiotropic branches of the plants (Figure 4).

A negative influence of Glyphosate drift was observed under the growth of the coffee plant, so that, by the replacement the dose of herbicide in the adjusted equation linear regression, at every $1 \%$ of the recommended dose, the height was reduced by $0.096 \mathrm{~cm}$, the leaf area in $35.31 \mathrm{~cm}^{2}$, leaf dry matter in $0.233 \mathrm{~g}$ and the dry matter of plagiotropic branches in $0.046 \mathrm{~g}$.
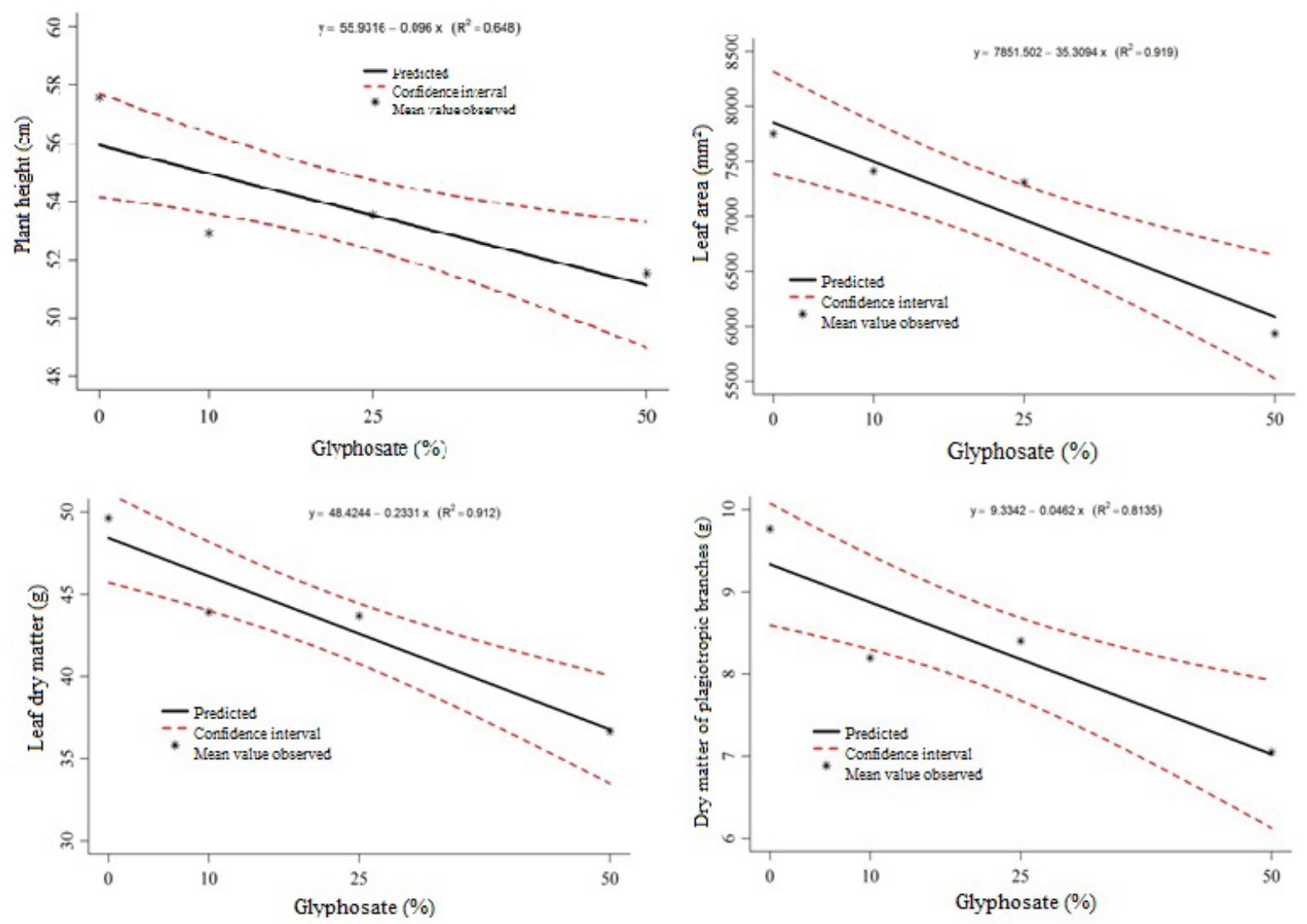

FIGURE 4 - Plant height, leaf area, leaf dry matter and dry matter of plagiotropic branches of coffee plants as a function of the effects of Glyphosate doses after 104 days at evaluation.
The decrease observed in the values of the studied characteristics may be associated with the mode of action of the herbicide, which acts on the secondary metabolism of the plant (VIDAL, 1997). The smaller leaf area caused a lower leafdry matter, maybe this happened due to the possibly reduction in chlorophyll synthesis, evidenced by chlorosis, and the absence of aromatic amino acid formation, the leaf increment of the plant was impaired (VIDAL, 1997). The smallest leaf area is directly related to leaf blade tightening, a phytotoxicity symptom observed at the highest doses of the herbicide (Figure 2).

However, the lower plant height and the lower dry matter of the plagiotropic branches in plants that received higher doses of Glyphosate can be explained by the possible reduction in syntheses of indole-3-acetic acid (IAA), since it is synthesized from tryptophan which, due to the inhibition of the chiquimate pathway by this herbicide, is not produced. 
Above all, the hormone indole-3-acetic acid is of great importance in the plant, responsible for cell expansion and maintenance of apical dominance, which is directly related to plant growth (GRUYS; SIKORSKI, 1999). França et al. (2010b) also report losses in the growth of coffee seedlings when submitted to the simulated drift of the herbicide Glyphosate.

\section{CONCLUSION}

The effect of glyphosate drift impairs coffee plant growth.

Leaf anatomy and physiology were not affected at 104 days after application of the herbicide.

\section{ACKNOWLEDGEMENTS}

The authors would like to thank CAPES, FAPEMIG, CNPq and EMBRAPA, for supporting this study.

\section{REFERENCES}

ALCÂNTARA, E. N.; FERREIRA, M. M. Efeitos de métodos de controle de plantas daninhas na cultura do cafeeiro (Coffea arabica L.) sobre a qualidade física do solo. Revista Brasileira de Ciência do Solo, Viçosa, v. 24, n.4, p. 711-721, Oct./Dec. 2000.

CAIXETA, G. Z. T. et al. Gerenciamento como forma de garantir a competitividade da cafeicultura. Informe Agropecuário, Belo Horizonte v. 29, n. 247, p. 1423,Nov./Dec. 2008.

CONAB. $2^{\circ}$ levantamento da safra de café 2017/ 2018. Brasília, 2018. Available in: $<$ https://www.conab. gov.br/info-agro/safras/cafe> Access in: June 2018.

CUNHA, J. L. X. L. et al. Comparação de métodos de área foliar em Chrysobalanus icaco L. Agropecuária Científica no Semiárido, Patos, v. 6, n. 3, p. 22-27, July/Sept. 2010.

FERREIRA, D. F. Sisvar: a computer statistical analysis system. Ciência e Agrotecnologia, Lavras, v. 35, n. 6, p. 1039-1042,Nov./Dec. 2011.

FIALHO, C. M. T., et al. Interferência de plantas daninhas sobre o crescimento inicial de Coffea arabica L. Planta Daninha, Viçosa, v.29, n.1, p. 137-147, Mar. 2011.

FRANÇA, A. C. et al. Teores de nutrientes em cultivares de café arábica submetidos à deriva de glyphosate. Planta Daninha, Viçosa, MG, v. 28, n. 4, p. 877-885, Dec. 2010.
FRANÇA, A.C. et al. Crescimento de cultivares de café arábica submetidos a doses do glyphosate. Planta daninha, Viçosa, v. 28, n. 3, p. 599-607, Sept. 2010.

FRANÇA, A.C. et al. Deriva simulada do glyphosate em cultivares de café Acaiá e Catucaí. Planta daninha, Viçosa, v. 31, n. 2, p. 443-451, June 2013.

GRUYS, K. J.; SIKORSKI, J. A. Inhibitors of tryptophan, phenylalanine and tyrosine biosynthesis as herbicides. In: SINGH, B. K. Plant amino acids: biochemistry and biotechnology. New York: Marcel Dekker, 1999, p. 357-384.

JORGE, L. A. C.; SILVA, D. J. C. B. SAFIRA: Manual de utilização. São Carlos: Embrapa CPDIA, 2010. 29 p.

LORENZI, H. Manual de Identificação e controle de plantas daninhas. $7^{\text {a }}$ Ed. Nova Odessa - SP. Instituto Plantarum, 2014. 384 p.

MATIEllo, J. B. et al. Cultura de Café no Brasil: manual de recomendações. Rio de Janeiro: MAPA/ PROCAFE, 2010. 542 p.

O'BRIEN, T. P.; FEDER, N.; MCCULLY, Mi E. Polychromatic staining of plant cell walls by toluidine blue O. Protoplasma, Leipzig, v. 59, n. 2, p. 368-373, June 1964.

OLIVEIRA, C. M., et al. Economic impact of exotic insect pests in Brazilian agriculture. Journal of Applied Entomology, Berlin, v. 137, n. 1-2, p. 1-15, Nov 2012.

REIS, L. A. C. Influência do glyphosate na anatomia e fisiologia de cultivares de café arábica. 2013. 61 p. Dissertação (Mestrado em Produção Vegetal)Universidade Federal dos Vales do Jequitinhonha e Mucuri, Diamantina, 2013.

RONCHI, C. P. et al. Acúmulo de nutrientes pelo cafeeiro sob interferência de plantas daninhas. Planta Daninha, Viçosa, v. 21, n. 2, p. 219-227, Aug. 2003.

RONCHI, C. P. et al. Efeito do 2, 4-D na produtividade do cafeeiro. In: SIMPOSIO DE PESQUISA DOS CAFÉS DO BRASIL, 2. 2001, Vitória. Resumos Expandidos..., Brasília: Embrapa Café; MINASPLAN, 2001. V. 1, p. 24-27.

RONCHI, C.P.; SILVA. A.A. Tolerância de mudas de café a herbicidas aplicados em pós-emergência. Planta Daninha, Viçosa, v. 21, n. 3, p.421-426, Sept./Dec. 2003. 
SEGATTO, F. B.; et al. Técnica para o estudo da anatomia da epiderme foliar de batata. Ciência Rural, Santa Maria, v.34, n.5, p.1597-1601, Oct. 2004.

SILVA, H., et al. Relationships between leaf anatomy, morphology, and water use efficiency in Aloe vera (L) Burm f. as a function of water availability. Revista chilena de história natural, Santiago, v. 87, n. 1, p. 13, July 2014.

SILVA, L. G., et al. Sintomas de fitotoxicidade e crescimento de mudas de café submetidas aos herbicidas inibidores da PROTOX. Coffee Science, Lavras, v.12, n.3, Sept 2017

TAN, S. et al. Herbicidal inhibitors of amino acid biosynthesis and herbicide-tolerant crops. Amino Acids, Vienna, v. 30, p. 195- 204, Mar. 2006.

TUFFI SANTOS, L. D. et al. Anatomia e morfometria foliar em clones de eucalipto tratados com glyphosate. Brazilian Journal of Biology, London, v. 69, n. 1, p. 129-136, Mar. 2009.
TUFFI SANTOS, L. D. et al. Danos visuais e anatômicos causados pelo glyphosate em folhas de Eucalyptus grandis. Planta Daninha, Viçosa, MG, v. 26, n. 1, p. 9-16, Jan./Mar. 2008.

VIDAL, R. A. Herbicidas: Mecanismos de ação e resistência de plantas. Porto Alegre, RS. 1997. 165 p.

WAGNER JR, A. et al. Deriva simulada de formulações comerciais de glyphosate sobre maracujazeiro amarelo. Planta Daninha, Viçosa, v. 26, n. 3, p. 677-683, Sept. 2008.

YAN, J., et al. High photosynthetic rate and water use efficiency of Miscanthus lutarioriparius characterize an energy crop in the semiarid temperate region. Gcb Bioenergy, San Diego, v. 7, n. 2, p. 207-218,Mar. 2014.

ZABLOTOWICZ, R. M.; REDDY, K. N. Impact of glyphosate and Bradyrhizobium japonicum symbiosis; with glyphosate-resistant transgenic soybean: a minireview. Journal of Environmental Quality, Madison, v. 33, p. 825-831, May. 2004. 